\title{
Old Boundaries and New Frontiers Reflections on the Identity of Archaeology ${ }^{1}$ Kristian Kristiansen
}

\begin{abstract}
In this paper I demonstrate some major changes within the traditional disciplinary boundaries of archaeology during the last 25-30 years, and the subsequent formation of new frontiers of theory and practice. They are the result of the expansion and diversification of the discipline in modern society. In that process archaeology has lost its former hegemonic identity which is replaced by pluralism and overlapping functions and identities. This has resulted in institutional and organisational discrepances. My analysis serves as a platform for formulating a strategy for cooperation between these new sectors, especially the heritage sector and the universities, leading to the formation of a more coordinated archaeological research practice.
\end{abstract}

Kristian Kristiansen, Department of Archaeology, Göteborg University, S-41298 Göteborg, Sweden.

While archaeology has achieved rather strong popular recognition among the general public in recent decades, archaeologists themselves seem to have been struck by an identity crisis. The symptoms are many: they range from theoretical oppositions to the nature of archaeological practice. There has evolved a gulf between different archaeological sectors: administrators and professional excavators, museum curators, monument managers and university lecturers - the latter being the absolute minority group, yet still defining the theoretical and methodological agenda. Museum curators and heritage managers have come to play the role of the silent majority - or have simply developed their own identity - with regard to education, books and journals, ignoring the so-called research environment.

Why has this gap appeared between the popular perception of the past on the one hand and the internal identity crisis of archaeology on the other, leading a former homo- geneous discipline to fragment into various new and disparate sectors? I shall propose that the two phenomena are closely interlinked - what happened to archaeology during the last 25 years can only be characterised as a revolution. Not since the formative days in the mid to late 19th century has the discipline undergone such major changes - involving all aspects, from theory and method to the practice and role of the discipline in society - as it did during the last 25 - 30 years ${ }^{2}$. The reasons are precisely to be found in the expansion and popularity of the discipline.

Today archaeology occupies a solid and respectable position in the modern welfare society as the authorized producer and reproducer of the national heritage. This position is in most countries safeguarded by legislation that secures the preservation, excavation and presentation of the archaeological heritage of the nation. Much of this new legislation, especially that concerning 
rescue excavations, was introduced during the 1960 s leading to the largest economic boom in the history of archaeology. In the process archaeological practice diversified to occupy these various new roles in society, and most archaeologists are today working within the so-called heritage sector. In my opinion the consequences of these changes have not been fully realized, especially not at the universities and in education, until quite recently. The next 10 years will see an adaptation of the research environment and of education to these new functions of archaeological practice, if they want to maintain their monopoly over education.
This will put great demands on universities and it may lead to a reorganisation of education, one reason among others being the interdisciplinary nature of archaeology.

More than any other historical discipline, archaeology is shaped by its place at the interface between different research traditions and different social and economic functions - between prehistory and history, between natural science and the humanities, between heritage administration and research, between the production of knowledge and the production of ideology, between the interests of the past and the present. To adapt successfully to the future one needs to ana-

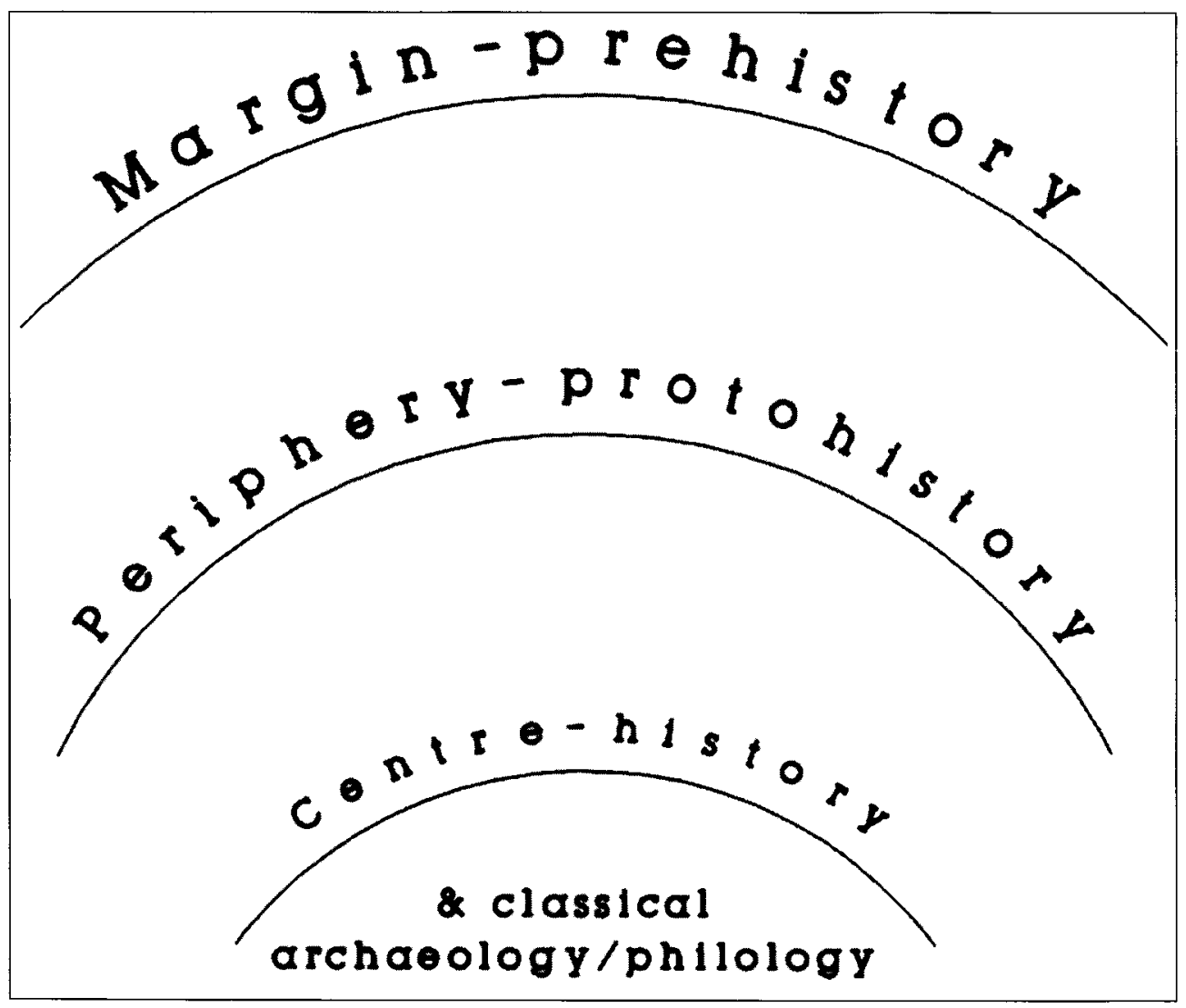

Fig. 1. Centre-periphery structure reflecting the disciplinary boundaries between archaeology and history. 
lyze and critically evaluate the relationship between these components, which define the academic and institutional boundaries of the discipline.

In the following I shall therefore discuss some of the more recent historical changes in the disciplinary boundaries of archaeology, which have led to the formation of new frontiers of archaeological theory and practice. As a consequence archaeology has lost its former hegemonic identity as a discipline, which has been replaced by a conglomerate of different, sometimes separate, sometimes overlapping functions and identities. Finally I shall evaluate the consequences of these changes in theory and practice for the future orientations of archaeology.

\section{BETWEEN PREHISTORY AND HISTORY}

Although archaeology, since the founding days of Thomsen, was explicitly defined by its source material - the silent material evidence of the past - there has nonetheless developed a dominant identification between archaeology and prehistory, that is history before the appearance of written sources. Historians, then, defined away archaeology from their realm, the history based upon written sources, relegating prehistory and archaeology to a position at the margin of civilization. This borderline reflects the old dichotomy between "civilization" and "barbarism", culturally determined preferences and value judgements which may deprive historians the ability to understand and recognize significant features of both civilized and barbarian societies. This is exactly what has happened, as the concept of civilization defines the relationship between prehistory and history through the occurrence of script and the survival of written evidence. In this way prehistory is pushed before the expanding frontier of civilization, defining arbitrary borderlines of historical research and explanation (Fig. 1).

In the Mediterranean history begins with the the Greeks and the Roman Empire, in central Europe with the Middle Ages or the Dark Ages after the fall of the Roman Empire, and in northern Europe first after the Vikings. The overlapping periods of the earliest script have been described by some as protohistory, indicating them as a field of both historical and archaeological research. The same is true of classical civilizations with their classical archaeology, which has gradually freed itself from art history and developed into a modern archaeological discipline.

This picture was valid until 25 years ago, and still is in some countries. Since then, however, major changes in disciplinary borderlines have occurred, especially in North America and in England, and from there they are spreading to the rest of the world, being recontextualized according to existing traditions (Trigger 1989; Hodder 1991).

First of all we must recognize the two basically different traditions or contexts of archaeology: in America archaeology originates from and is still considered part of anthropology, while in Europe archaeology at an early stage was linked to history and natural science, especially to geology. This has to some extent determined the expansion of archaeological practice that took place during the last 25 years. During this period traditional archaeology freed itself from the constraining temporal boundaries and began to include first medieval then later historical epochs, culminating with the archaeology of our own time (Fig. 2).

There were several reasons for this development: the growing heritage sector protected increasingly historical archaeological monuments, and in the new national agencies there developed an interdisciplinary management environment, where archaeologists, historians and architects worked together in excavating, recording and restoring historical sites and monuments. Also the protection of historical landscapes was increasingly linked to archaeological 


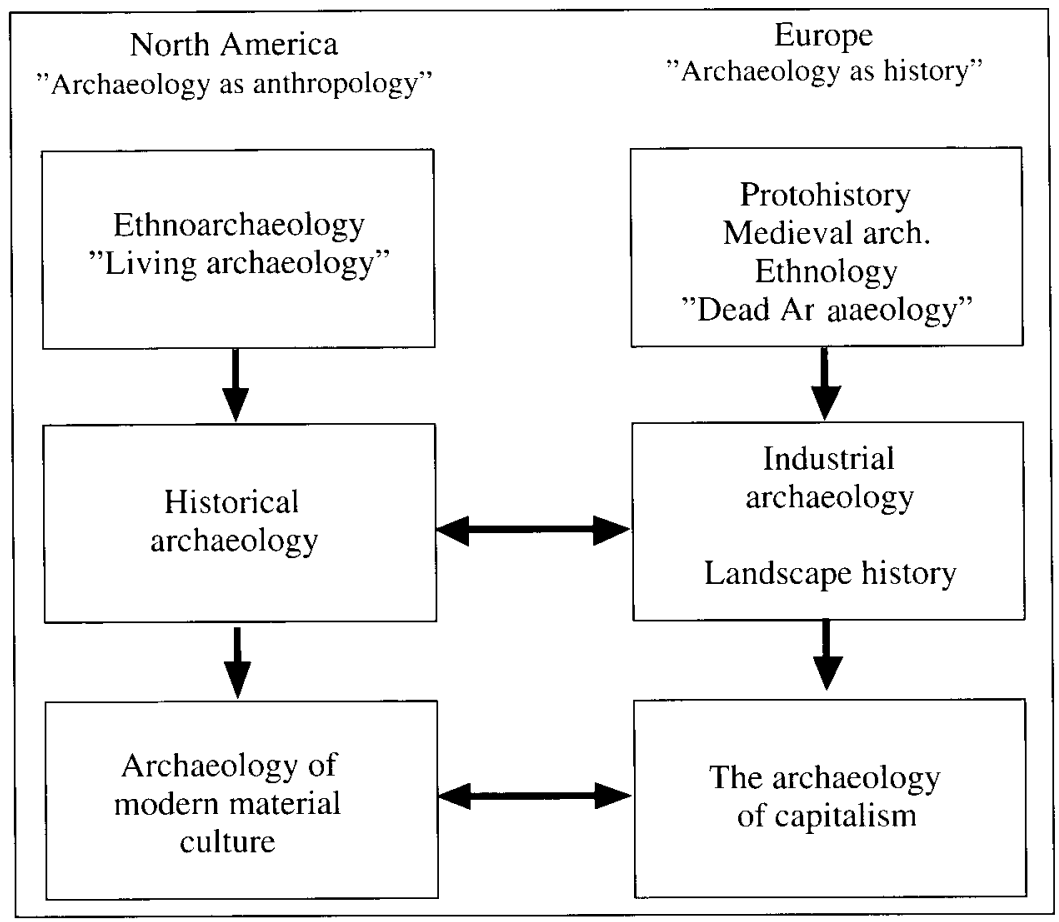

\begin{abstract}
Fig. 2. Major trends in the expansion of archaeological practice in North America and Europe during the last 25 years.
\end{abstract}

surveying. Academically there developed at the most innovative university departments a theoretical need to carry out archaeological research under historical control (ethnoarchaeology, historical archaeology) which gradually evolved into a new research paradigm (Binford 1983; Hodder 1982a, 1982b), and finally there developed in North America a strong interest in colonial archaeology - the living conditions of Indians and settlers and the formation of American culture, which was only sporadically covered by historical sources (Deetz 1977; Leone 1984). This was followed by a more sociologically inspired concern with the function and role of modern material culture (Rathje \& Schiffer 1980: 380ff.; Rathje 1979), which also gained some foothold in Europe (Shanks \& Tilley 1987: Ch. 8). In Europe urban expansion at the same time led to an expansion of medieval and later historical (rescue) archaeology, which gradually evolved into other forms, such as industrial archaeology, the archaeology of capitalism and the archaeology of indigenous peoples (Gledhill, Bender \& Larsen 1988; Miller, Rowlands \& Tilley 1989; Layton 1989).

These developments are summarized in Fig. 2. for North America and Europe, respectively. They have created a whole new disciplinary frontier between archaeology, ethnology, the history of technology, and social anthropology, to mention the most important. Ethnoarchaeology quite naturally grew out of the anthropological tradition in America, but today it occupies a position as a recognized archaeological practice also at several European universities. Likewise urban and industrial archaeology grew out of a European tradition, just as landscape history has increasingly become a new field of interdisciplinary research and conservation, constituted by human geography, landscape history and archaeology (Hyenstrand 1983; 
Berglund 1991; Hodges 1991).

It is still too early to evaluate the future impact of these new frontiers on archaeological theory and practice, but I shall make an attempt in my concluding statement. We can, however, observe that historical archaeology is gaining foothold in England and Sweden especially. Stig Welinder has carried out important case studies (1992 and 1995), just as the Central Board of National Antiquities has a whole department dealing with landscape history and conservation. It links up well with the Swedish tradition of human geography, as exemplified by the journal Bebyggelsehistorisk tidskrift (Journal of Settlement History). The same is true in England with its tradition of landscape archaeology and settlement history (Fowler 1972; Hodges 1991). The combination of nature conservation and historical conservation at a national and European level will then eventually provoke the further development of historical archaeology and landscape archaeology in Europe (Macinnes \& Wickham-Jones 1992; Bender 1993; Roymans $1995)^{3}$ - the cultural environment being the new integrating concept (Welinder 1993; Kristiansen in press).

\section{BETWEEN SCIENCE AND THE HUMANITIES}

The natural sciences - geology and zoology especially - were important contributors to the formation of archaeology as a scientific discipline. Principles of geology, and the zoological determination of stratigraphically layered bones and shell middens, formed the basis of the first recognition of an early Stone Age of hunters and fishers in Europe. This breakthrough took place in Denmark (Fischer \& Kristiansen in press) and in France (Grayson 1983) during the 1850s. It helped to free archaeology from the at that time rather unhappy status as an auxiliary discipline to history, illuminating historical myths. This was most clearly realised by Worsaae, who used the new results cleverly to establish

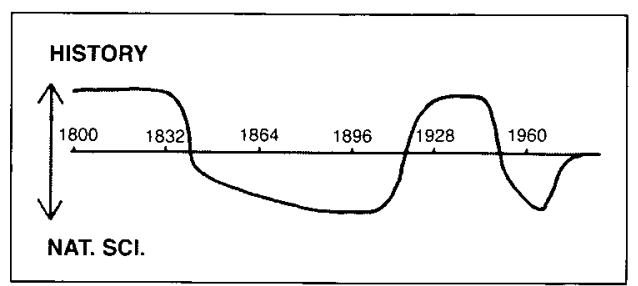

Fig. 3. Graphs showing the prevailing explanations of the Bronze-Iron Age transitition in Scandinavia according to their reliance on natural science or culture-historical factors (after Sörensen 1984).

archaeology as a discipline in its own right, contributing to the emerging acceptance of the evolution of Mankind which had been launched by Darwin during the same period. It further laid the foundation for a permanent cooperation, if not integration, between archaeology and the natural sciences, which has grown in scale and in subjects ever since. Today archaeology would be unthinkable without the assistance of environmental sciences, zoology, the natural sciences of age determination, and technological and medi$\mathrm{cal} /$ physical sciences.

Also indirectly the impact of a position between science and the humanities has been strong. This is reflected in the basic methods of classification, which in archaeology are much more rigid and scientific than in most other humanistic disciplines, perhaps with the exception of linguistics. The naturlisation "taken for granted" in these highly scientific methods of excavation, recording and classification has been criticized in recent years, most strongly by Shanks and Tilley, who argue that it homogenises the archaeological data and thereby also their interpretation, leaving too little scope for discussion, reflection and alternative interpretations (Shanks \& Tilley 1987: ch.3; Hodder 1989; Tilley 1989). This is of course a basic dilemma in all science, but the debate reflects once more 


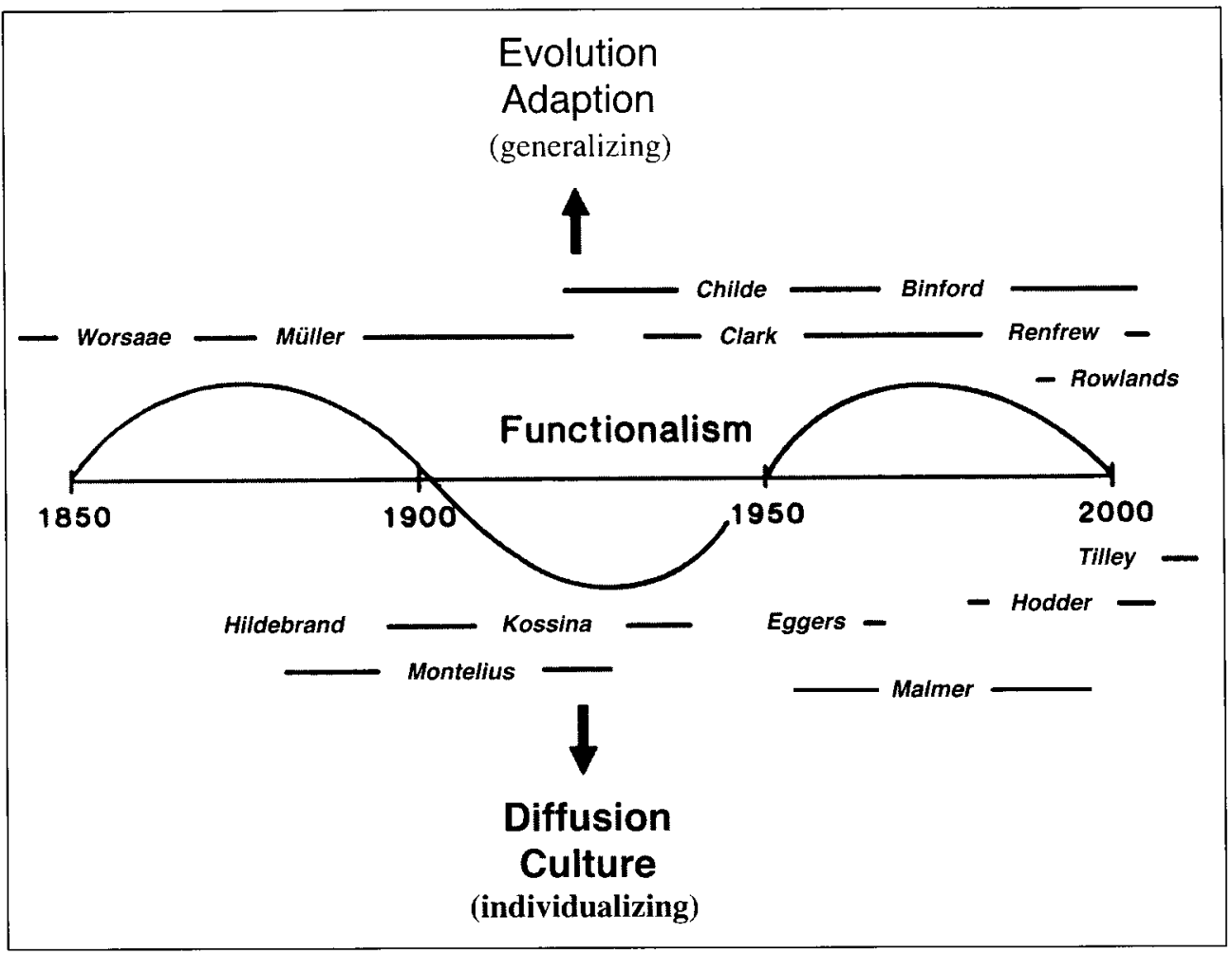

Fig. 4. Graph suggesting the prevailing interpretative frameworks in European archaeology during 150 years.

archaeology's position between science and the humanities, and it suggests that the boundaries between them are not static, but subject to change.

This has been demonstrated in a work by Marie Louise Stig Sørensen (1984). In an historiographical analysis of the Bronze-Iron Age transition she classified the prevailing explanations according to their reliance on natural science or culture-historical factors. It revealed a cyclical change in the dominance of one or the other over time (Fig. 3). If we then compare this with a more subjective diagram of cyclical changes over time between the dominance of general evolutionary explanations versus culture-historical explanations in archaeology, they follow on the whole the same pattern (Fig. 4). It suggests a wider world-historical regularity linked to civilizational cycles of hegemony and cultural identity, as discussed by Friedman (1989).

Turning to more recent changes in the relationship between science and the humanities, we note that the rise of New Archaeology or processual archaeology was heavily inspired by the terminology of science, both in basic classification methods (beginning already during the 1950s) and in theory and testing procedures (from the 1960s onwards). The theoretical shift during the last decade towards a post-processual, culture-historical and contextual archaeology has been accompanied by a retreat from former quantitative 
methods of analysis and been replaced by a return to historical interpretations and hermeneutics (Hodder 1986). This shift towards the humanities and culture, however, has also introduced or reintroduced a critical concern with the use of the past in the present, by employing critical theory, a most welcome and much needed approach for the heritage sector whose work is so closely interwoven with the ideological fabric of historical identities (Pinsky \& Wylie 1989; Baker \& Thomas 1990). Also the contextual concern with the particular, including the individual monuments, suits the heritage well, and one may observe an increasing theoretical and interpretative concern with such problematics in recent writings, from Richard Bradley's monument narratives in Altering the Earth (1993) to Michael Shank's much debated book Experiencing the Past (1992) among other things a polemic against the traditional presentation and use of archaeological monuments. Post-processual and contextual archaeology, however, has also been criticized for being out of touch with the practice and experiences of heritage archaeology (Smith 1994).

Today archaeology finds itself in a middle position between science and history, a productive pluralism which may hopefully continue for some time yet. According to the historical regularity of the cycle, this will not last. In that case, the historical disciplines can look forward not only to further popularity and expansion, but also to systematic attempts at political manipulation and misuse, as is already the case in several parts of Europe. This rather gloomy perspective leads to a discussion of knowledge and interest.

\section{BETWEEN KNOWLEDGE AND INTEREST}

The title of this section is a slightly modified translation of a classical work by Jürgen Habermas, Erkenntnis und Interesse, which appeared more than 25 years ago (in 1968, reprinted 1973) and at that time opened up a still ongoing debate about the relationship between the production of knowledge and the use of that knowledge in society. The debate reached archaeology first in the late 1970s and early 1980s - symptomatically, and in accordance with Habermas' theory, at a time when the full impact of archaeology's enrollment in the political - administrative system of the modern welfare society became apparent.

From 1965 onwards, resources and new jobs at museums and in the heritage sector expanded as rapidly as the increasing numbers of students and graduates from the universities (Fig. 5). At the time, that is during the late 1960s and 1970s, this was seen as an unproblematic, good thing. Archaeology was considered to serve the historical needs of society in a rather straightforward way. The biggest problems were considered to be internal - the lack of a theoretical and methodological framework enabling archaeologists to analyze and explain the past in more scientific ways, and in ways more relevant to society. Social organisation, economy and ecology became key factors. The decay and the transformation of the archaeological record from the past to the present were rigorously analyzed in order to eliminate distortion (Schiffer 1987). However, distortion arising from the present, the use of the past in the present, was only gradually acknowledged as worthy of serious consideration.

During the last $10-15$ years research on the social and ideological functions of archaeology, in tandem with the realities of archaeological practice under increasing pressure from different interests in society, has made the relationship between the past and the present increasingly clear (Keller 1978 and 1991; Mahler et al 1983; Myhre 1994; Pinsky \& Wylie 1989). Or as formulated recently by Ian Hodder: "It is difficult to be a European archaeologist and remain unaware of the ways in which historical and social conditions have shaped the way excavations, 
63646566676869707172737475767778798081828384858687

500

400

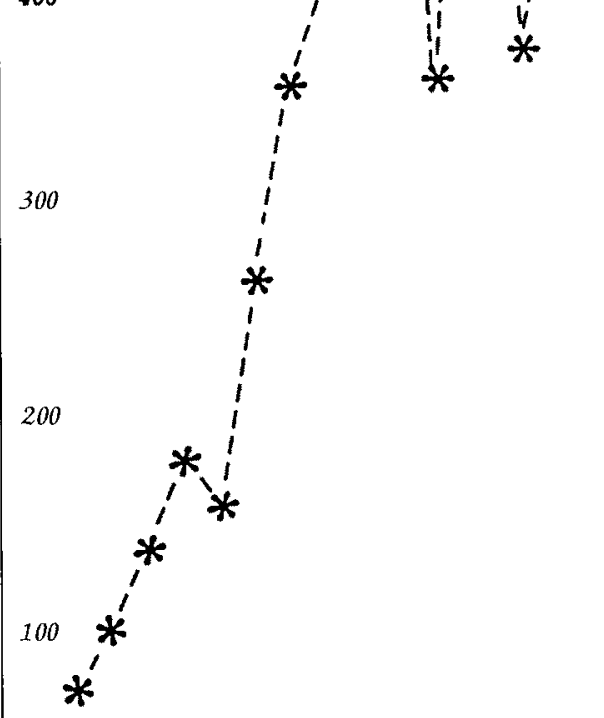

63646566676869707172737475767778798081828384858687

300

200

100

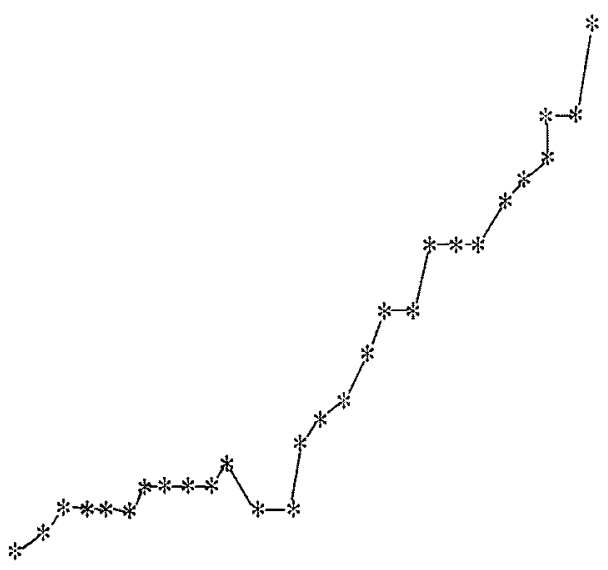

Fig. 5b. Frequency of registrated Ph.D. students in archaeology in Sweden between 1958 and 1989 (redrawn after Nordbladh 1991). 


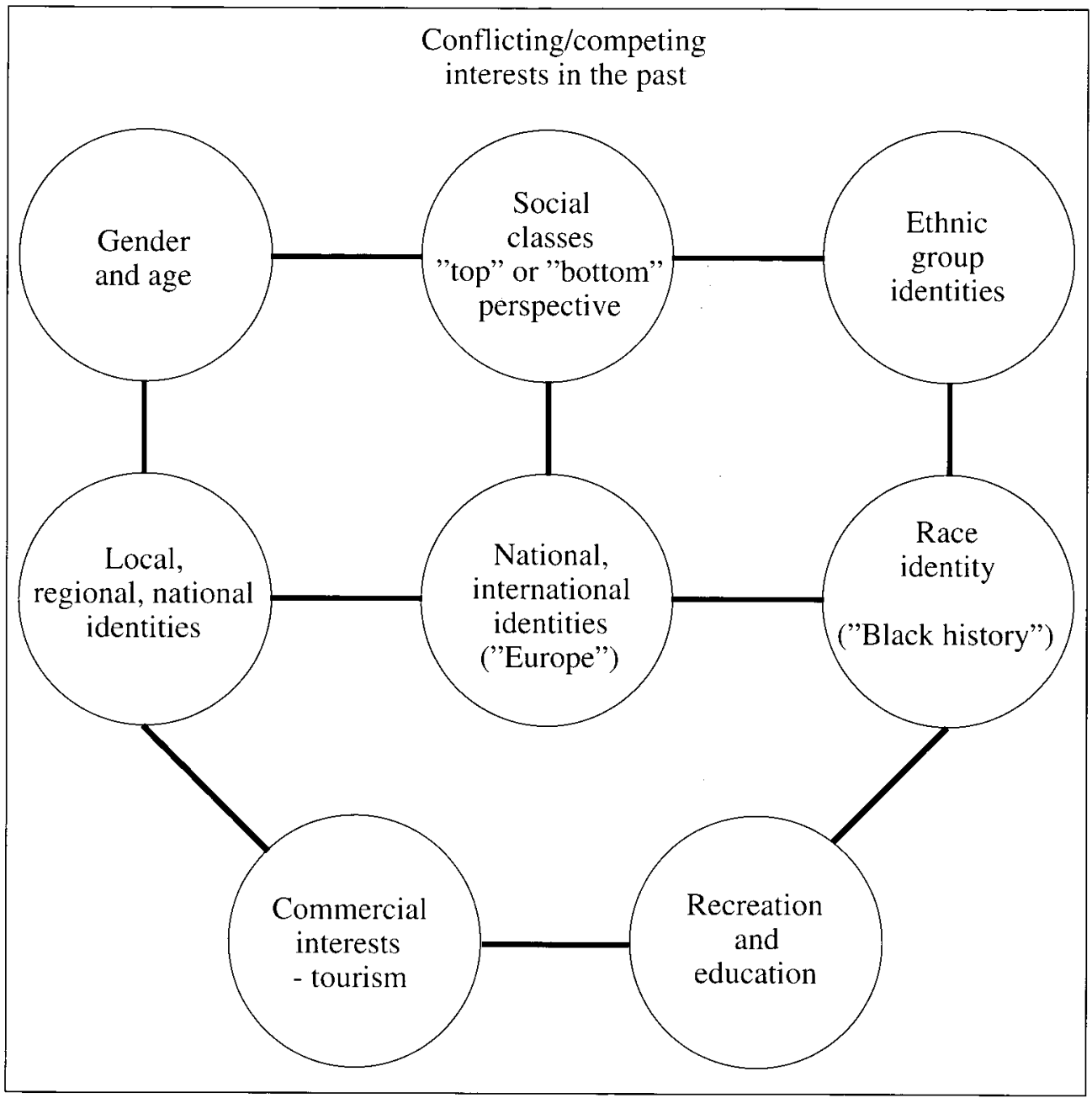

Fig. 6. Scheme of competing and conflicting interests in the past.

analysis and interpretations are caried out." (Hodder 1991:19). I would add two more words: "and used". It is the use of the past for the purposes of the present which is so characteristic of archaeology.

One of the most important functions of the past is as creator of national/ethnic identity and unity. This is probably the main reason for the existence of archaeology, museums, and preservation laws, and for the importance attached to history as a school sub- ject, on par with arithmetic and mathematics. The past is one of the cornerstones of the images we have of the world we live in, as developmental history, from the Stone Age to the Industrial Age, and as national and ethnic history. This has been demonstrated in many recent studies (Lowenthal 1985; Hedeager \& Schousboe 1989). But in that historical process archaeology has been employed by different social classes in their rise to political dominance, as demonstrated 
in the case of Denmark (Kristiansen 1981 and 1993). Today nationalism is once again marching forward and employing archaeology and history to invent new myths of origin (Slapsak 1993, Kohl 1993). In fig. 6 I have arranged a whole array of conflicting and competing interests which use the past. Tourism and the revival of national heritage has turned out to be a most efficient cocktail (Boniface \& Fowler 1993; Prentice 1993). Tourists are the pilgrims of our time, visiting well-presented historical shrines on their fixed routes and carrying souvenirs back home instead of relics (Horne 1984) ${ }^{1}$.

Archaeology has always served both the past and the present, and the question to be asked, therefore, is whether the future will see a changed balance between the interests of the present and what effect that may have on archaeological practice (Gillberg \& Karlsson 1994; Riksantikvarieämbetet 1993). I have already mentioned the two dominant interests - nationalism and ethnicity on the one hand (Shennan 1990; Kontaktstencil XXXV), and tourism on the other (Prentice 1993). The increasing interest in the historical heritage will probably reinforce the contradictory aspects of historical change - the social aspects of early industrial society, the archaeology of war, and following in the wake of that probably the archaeology of emigrants. Opposing that will be demands for reinforcing national historical myths and histories in some countries, as is already apparent, some times openly but mostly in subtle ways.

What is new, is probably a growing consciousness in the archaeological community

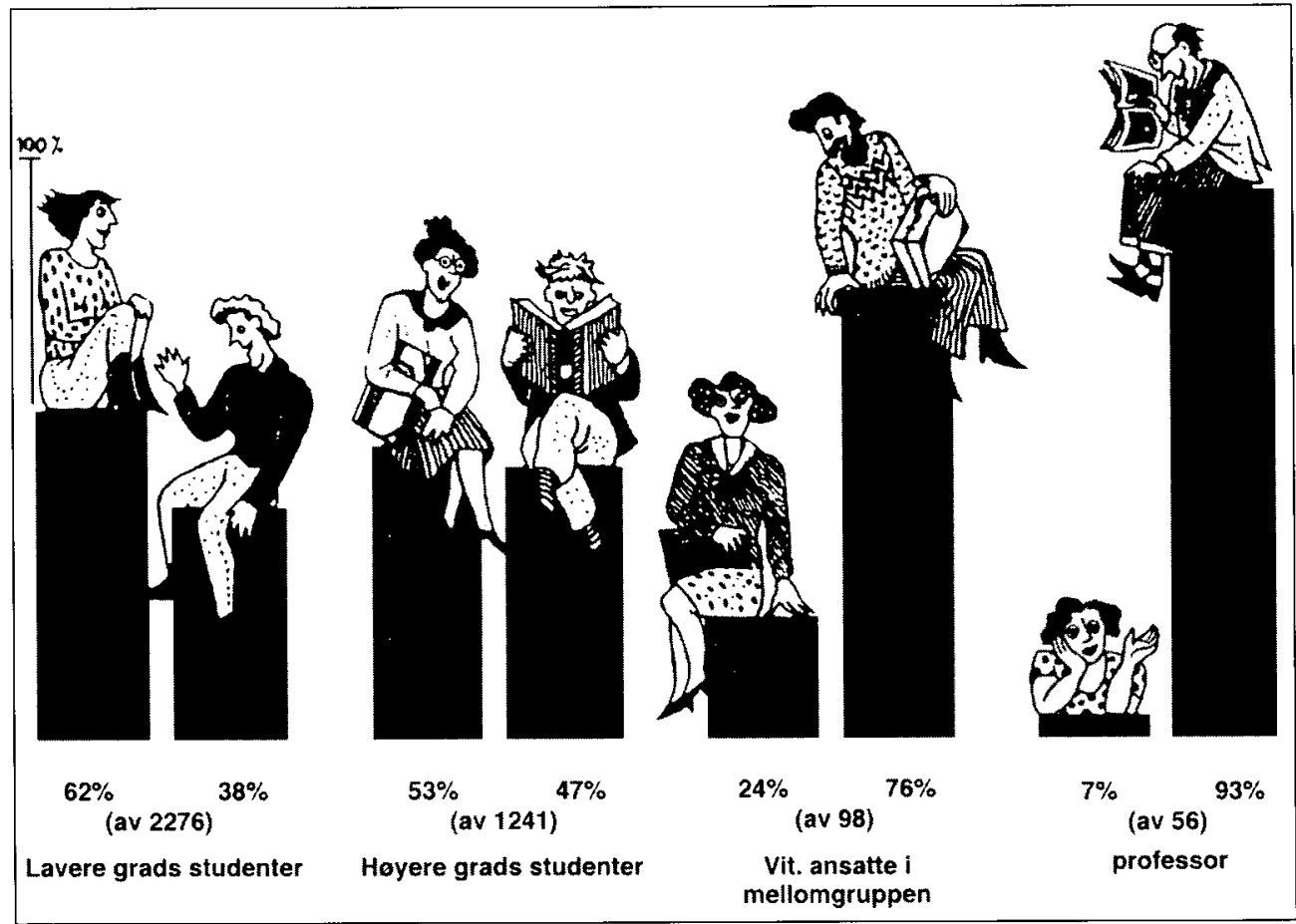

Fig. 7. Male-female representation in Norwegian archaeology in 1985. 1) undergraduate students, 2) Ph.D. students, 3) employed in archaeological positions, 4) professors/directors. The trend is symptomatic for most European countries (after Näss 1991). 
that not only archaeological results - books, monument presentations etc., - are subject to use and misuse. The social context of archaeology is also linked with these problems (Baudou 1991; Nordbladh 1991; Näss 1991). Questions of gender also originate in the social organisation of archaeology itself, women being increasingly under-represented, from students to professors and museum directors (Fig. 7). The fact that many, perhaps most, archaeologists today are working within the administrative framework of the public sector, and that many museums are dependent upon commercial success for their survival, also contributes to sharpen the understanding of the politics of the present in the archaeological environments (Welinder 1995).

Thus the implications of the relation between past and present, between interest and knowledge, should be an ever-present ingredient in archaeological theory and practice, both in education and when discussing the future direction of the heritage sector.

\section{BETWEEN MANAGEMENT AND RESEARCH}

Archaeology prior to 1965 was basically a museum- and research-based discipline carried out at the larger museums and in a few university departments. Archaeological practice was on the whole without administrative obligations, except those mainly internal ones linked to museum work and small-scale excavations and conservation. There remained room for a rather large degree of freedom to choose excavation and conservation projects, and exhibitions were rarely renewed more than once in a lifetime. Between 1965 and 1990, that is within 25 years, peace disappeared as new legislation all over Europe and the Western world enrolled the cultural heritage, including archaeology, in the administrative system of the welfare state, leading to the formation of new national agencies (English Heritage, State Antiquaries in the Nordic countries), and county and mu- nicipal administrations dealing with the historical heritage of monuments, sites, buildings and historical landscapes. This development changed the whole organisational profile of archaeology, the role of research and the decision-making structure of excavation and conservation. Today basic research plays only a modest role in comparsion with resources allocated for rescue-excavation, registration and conservation.

As it has been a gradual development, the more basic problems concerning the overall direction of and responsibility for archaeological research have not been fully realised. Archaeology has on the whole maintained its old research structure, although the production of new evidence has increased probably by a factor $10^{5}$. This discrepancy is now beginning to cause severe problems. In the past, concerns have been mostly with the backlog of unpublished excavation reports rather than with the overall structure of archaeological research (but see Renfrew 1983; Baudou 1991; Tilley 1989) ${ }^{6}$. Today, however, the overriding problem is that existing research environments and research funds were never geared to the present output of rescue archaeology (Thomas 1991). It means, quite simply, that the research environment does not have the capacity to transform the volume of archaeological data being produced, into historical knowledge. To overcome this dilemma demands a rethinking of the whole framework for rescue and research, leading to new forms of cooperation between heritage management, museums and university departments.

Thus the heritage sector is today responsible for producing most of the archaeological knowledge available for future research. In the process there has developed a new field of academic/bureaucratic skills and of applied research, giving status and merits to its practitioners. This is to be welcomed, and it may serve as a basis for a more balanced cooperation with the traditional research environment at universities and museums 
(Fig. 8).

The basic research problem facing the archaeological environment in creating this new balance between rescue and research, however, is that there exists a divide between universities and the heritage sector in many countries. Although various types of advisory boards assist in making priorities, no one feels responsible for developing the enormous and continuous accumulation of new evidence into meaningful research projects at a national level. This is not to deny that important excavations and registrations are published, but there exists no overall research strategy and no money to make sense of the majority of the evidence: it is dead capital. This locked situation is the result of overlapping responsibilities, leaving comparative research above the level of the individual site as an ill-defined responsibility. The only way out is to define this responsibility. It implies that rescue archaeology assumes full responsibility - not only for documenting the archaeological past before destruction, but also for developing and financing integrated research programs in col- laboration with universities and museums ${ }^{7}$.

Such an integration may be supported by recent developments within the heritage sector itself. Here the boundary between legislation/administration and its practical implementation in the form of restoration, excavation, registration, etc., is now increasingly subject to change. It has become commonplace to separate administration and applied research, especially within the larger environmental sector. New sector research institutions are established to secure a degree of independence on the one hand, and a proper research environment on the other. An opposing tendency is to privatise some of the work, especially excavations, which rather represents a fragmentation of the research environment.

So we can observe three tendencies for the future development of research and heritage administration:

- the autonomy model (or the centralized model), which maintains most of the research within the heritage sector itself, eventually in special sector research institutions, by allocating existing laboratories, excava-

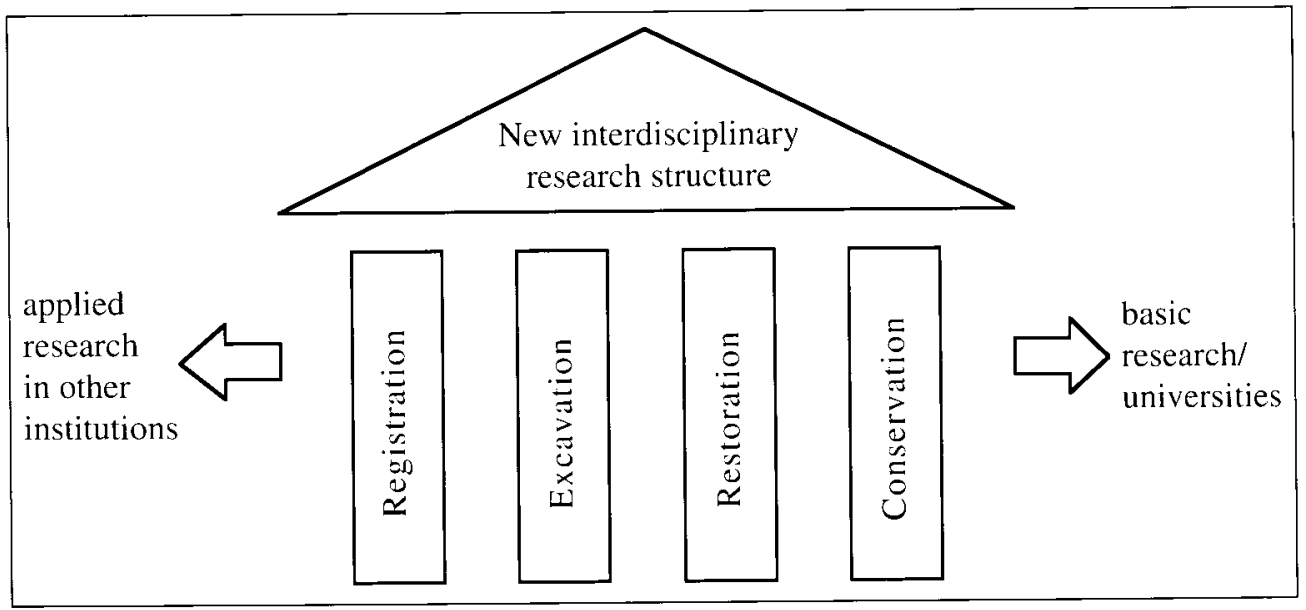

Fig. 8. Generalized model of the Heritage House, with its four pillars of basic activities, which in later years has been roofed by an expanding superstructure of applied research. This development has given the heritage sector a central position in the development of new research strategies and topics. 
tion and restoration units. The Royal Commission in England represents a good example of such an institution, and so does the new Norwegian Organisation NIKU (Norwegian Institute of Cultural Heritage Research), or the Swedish and Dutch models of a national organisation of rescue archaeology, although regionally divided.

- the integrated model (or decentralization model), distributing the work to museums or research institutions/universities or to both. This may also include post-education, postexcavation and publication. The museum model is dominant within Danish archaeology, as one of the few countries that maintained and modernized the museum structure to include rescue archaeology. In most other countries universities and regional rescue units of various kinds has taken over. This model have in several cases led to an integration with the final model.

- the privatisation model, where part of the work is privatised according to principles of cheapest and most qualified bids. This is the American model, which unfortunately is spreading to Europe, although mostly in a watered-down version, avoiding the worst pitfalls of the American experience, e.g., by developing specialist services or by stressing regional competence.

All of these trends, which tend to break up or lead to a reorganisation of existing structures $^{8}$, speak in favour of developing closer ties between the heritage sector and the universities in order to maintain both a critical debate and the development of relevant (critical) and more unified skills of both theory and practice. It is important to stress that, regardless of the variety of organisational solutions adopted in different countries, some level of coherence and continuity must be maintained - from planning to publication, from "on the ground priorities" to regional and national research programs. This is a prerequisite for productive research, leading to a final discussion about the role of education in the changing archaeological en- vironment of the 1990s.

\section{BETWEEN EDUCATION AND RESEARCH}

In the preceding sections I have delineated some developments in archaeological theory and practice that have radically transformed the discipline and created new disciplinary boundaries and frontiers. In the final section I shall discuss which of the frontiers will develop into more stable boundaries of archaeological practice and which will remain open to further development. And finally: how can and should the universities interact with and transform some of these new practices into relevant research and education?

I have identified three major fields or frontiers of new archaeological practice:

- historical archaeology/landscape history, integrating archaeology with human geography and ethnology

conservation and heritage management, integrating archaeology with architectural history, planning, law and politics.

culture and environment, integrating archaeology with ecology, history and ethno$\log y$.

To this I would add the role of archaeology and of archaeological heritage in modern society as a fourth frontier of archaeological research and practice.

Each of these new frontiers challenges the identity of former autonomous disciplines, such as ethnology, human geography and architectural history, just as it challenges the prevailing identity of archaeology.

If we next consider the present organisation of learning and research at the universities, and the organisation of museums and heritage agencies (Fig. 9), the discrepancy especially between universities and the heritage sector is apparent. Education and research is still organised according to rather traditional and narrow specialist subjects, separated either by period or object. This structure originated in the late 19 th century, 

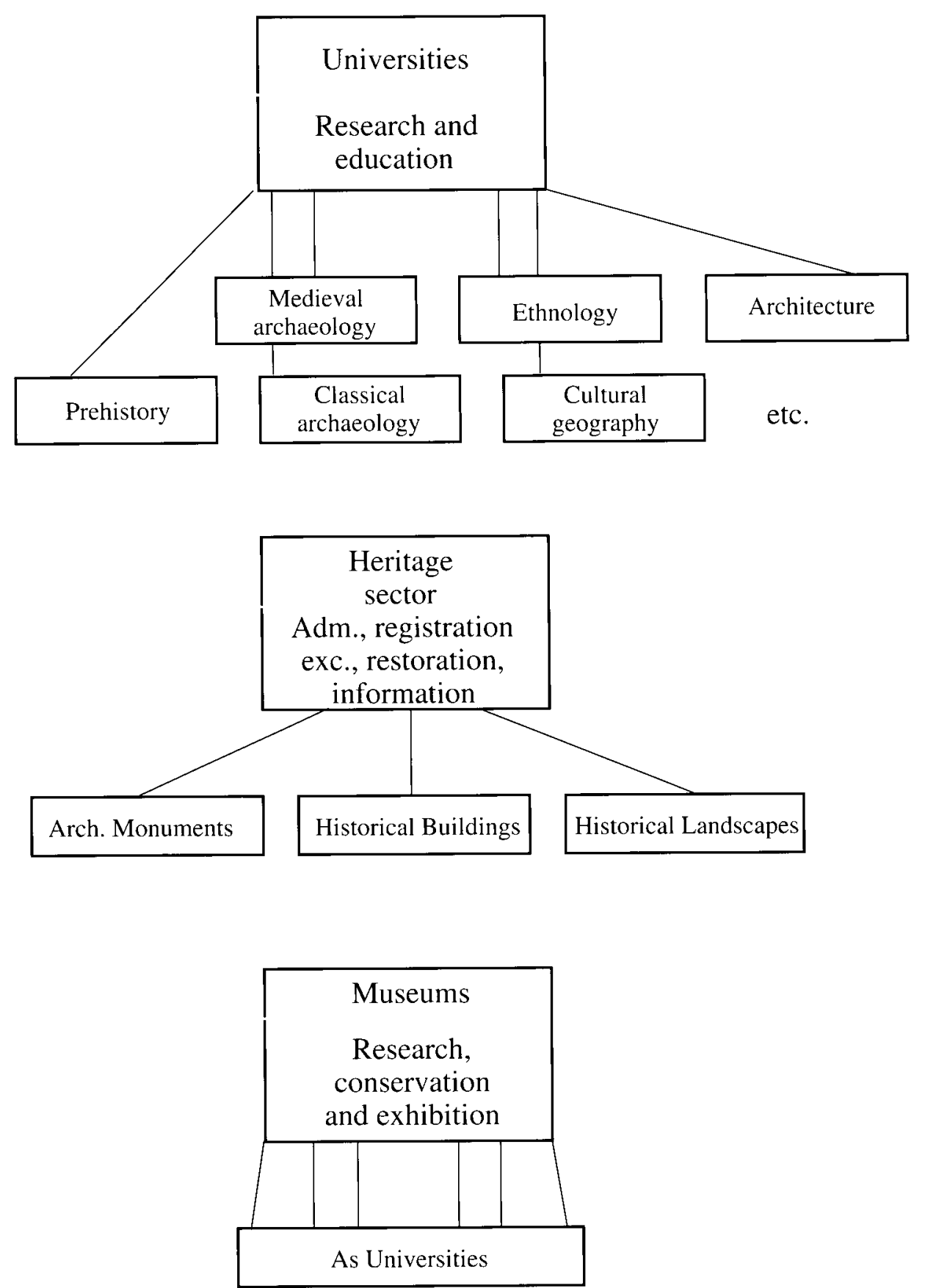

Fig. 9. Organisational models of the prevailing institutional and disciplinary boundaries at universities, in the heritage sector and at museums. 
as did museums, which explains their organisational similarities. The heritage sector, on the other hand, is generally much more interdisciplinary in its subject matter and consequently also in its organisation. Besides, there has developed a whole new sector of applied research which cross-cuts the traditional boundaries. At the more innovative universities these developments and needs of society are reflected in the formation of interdisciplinary research centres, just as many smaller disciplines are lumped together in larger departments, though often without any real integration of research and education.

We are thus experiencing a period of major transformation of society, demanding new forms of knowledge in addition to the traditional forms. Archaeology is no exception from this pattern; on the contrary, it faces bigger organisational problems because of its interdisciplinary nature. How should the universities respond to this challenge?
This question touches upon some basic principles of university ideology, as it raises questions about the demarcation line between autonomy versus dependency, critical research versus applied research. Responses have ranged from rejection to the formation of new departments of applied research and teaching. I shall briefly discuss three possible approaches and their implications.

The first I shall call the "hands off" approach, stressing the critical autonomy of university education and research. The philosophy is to wait and see which of the new needs will come to occupy relevant and definable areas of new knowledge and research. If the university always adapts to the immediate needs of society in the short term one may lose the necessary critical distance and lose sight of important long-term trends.

Secondly we have the "hands on" approach. It is chararcterized by a conscious critical cooperation, based on the philosophy that it is possible and necessary to incor-

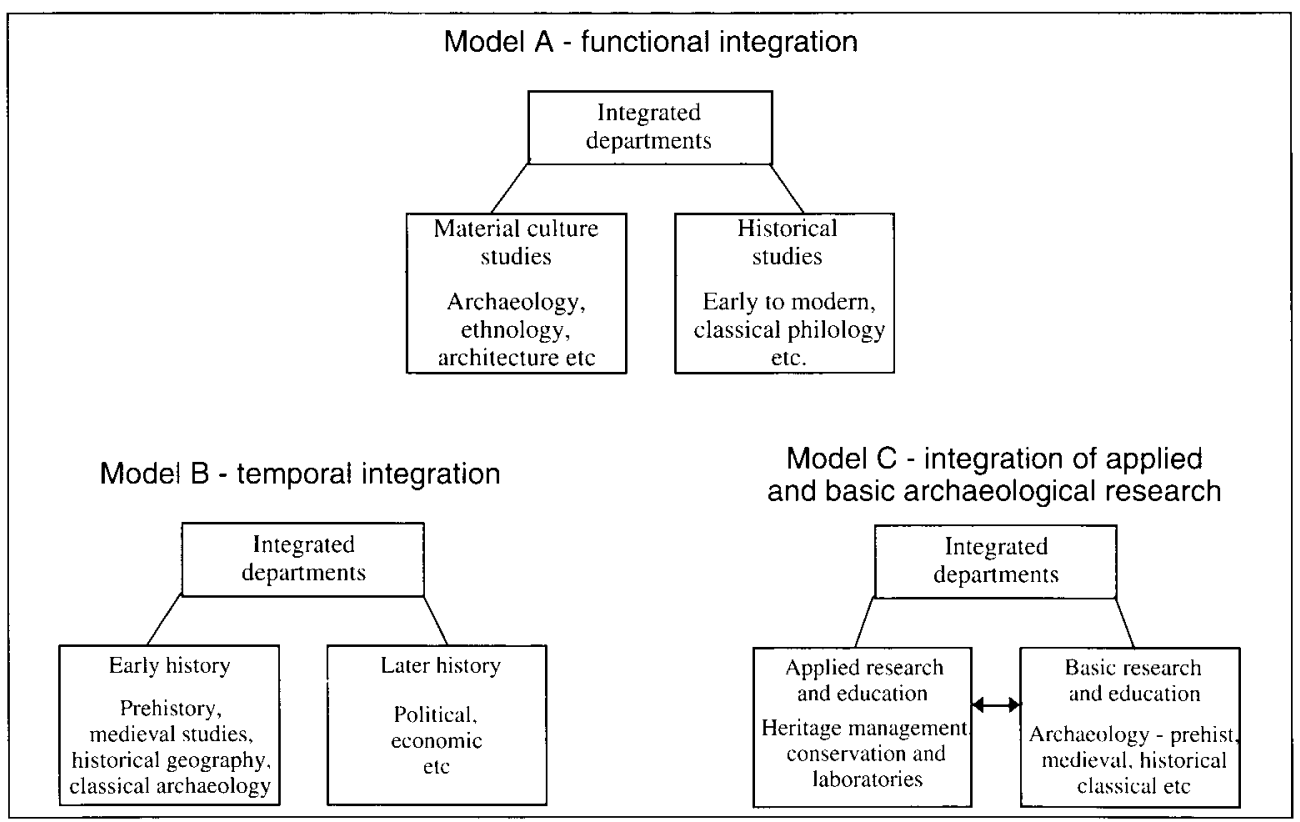

Fig. 10 Three alternative models for a more integrated structure of research and education within the culture-historical disciplines. 
porate new areas of research and education into a reciprocal process of learning. In other words the universities have to keep in touch to stay alive, but without selling their soul.

Finally there is the "hands in" approach. It is based upon the philosophy that if you don't adapt to the needs of the market you won't survive, because that's where the money is. Or put more academically - universities serve the needs of society, and should actively engage in taking up new fields of applied research and education, otherwise they will become too esoteric and lose their monopoly over education in the long run. This is already happening in some countries.

My own approach is closer to the second: I believe universities should engage in a critical dialogue and a closer cooperation with those who employ the students, especially in periods of changing needs, when new forms of knowledge are being created. In fig. 10 I have illustrated three models for integrating the new archaeological frontiers into a future organisation of research and learning, which will gradually transform them into new disciplinary boundaries. Model A is based upon functional integration and it takes material culture as its principal point of departure, creating an integration between archaeology, ethnology, museology and heritage management. Model B is based upon temporal integration and takes the major historical time periods as its point of departure. It integrates early history, prehistory, medieval studies, classical archaeology and philology. Finally Model $\mathrm{C}$ represents an extended functional version of Model $\mathrm{A}$ and Model $\mathrm{B}$, dividing them into a department of applied research and education, dealing with heritage management, conservation and laboratories and a department dealing with basic research and education.

Only by taking up the challenge and attempting to integrate new and old sectors of archaeological practice will it be possible to maintain a dialogue between the different archaeological sectors in the future. Archaeology has become a multi-functional, theoretically diversified discipline. Despite such diversification and pluralism, it is necessary for any discipline to maintain some common theoretical and methodological ground to maintain credibility as a discipline and to be able to resist political manipulation. Dialogue and cooperation are the means to ensure that.

\section{SUMMARY AND CONCLUSION}

In this paper I have demonstrated some major changes within the traditional disciplinary boundaries of archaeology and the formation of new frontiers of theory and practice. They are the result of the expansion and diversification of the discipline in modern society. In the process archaeology has lost its former hegemonic identity, which is replaced by pluralism and overlapping functions and identities. This has resulted in institutional and organisational discrepancies. My analysis served as a platform for formulating a strategy for cooperation between these new sectors, especially the heritage sector and the universities, leading to the formation of a more coordinated archaeological research practice.

This is not a return to a hegemonic past archaeology has forever lost its closed academic character - it is rather a realisation that archaeological practice is today so diversified and extensive, that new organisational structures and means of communication are needed to secure an efficient use of the available resources and the available archaeological evidence for research and education.

English revised by Laura Wrang. 
'This article was originally delivered as a lecture (provföreläsning) in April 1994 in Gothenburg in connection with the competition for the professor chair of archaeology. I have added some recent literature.

${ }^{2}$ It resulted in a need to take stock of the changes and their implications, from archaeological history (Hodder 1991; Meltzer et al 1986, Trigger 1989) to monuments and museum collections (Hyenstrand 1984; Kristiansen 1985; Jensen 1992). These historical analyses served also as a platform for reformulating research and conservation strategies (summarized in Hyenstrand 1995).

${ }^{3}$ Politically there is at the European level an increasing understanding of the idea of historical landscapes, following upon a period dominated by the conservation of buildings and architecture. It is reflected in the work of the Council of Europe, presenting a new charter on the conservation of historical landscapes. In the Scandinavian countries the concept of the cultural environment has been employed by the national heritage agencies to forward a more unified strategy of landscape conservation and presentation.

I am not dealing with how people, the visitors and consumers of the past, perceive it. This is a growing research topic (Adolfsson 1987; Andersson, Dahlgren \& Jennbert 1995: Merriman 1991), with significant economic implications.
${ }^{5}$ In England it has been estimated that the last 20 years have seen more excavations than were undertaken during the preceding 130 years (Thomas unpublished).

${ }^{6}$ Several conferences in both Europe and North America have in recent years been dealing with at least some of these problems, namely those linked to rescue archaeology, which lies closer to the heart of most archaeologists than conservation or landscape archaeology (e.g. Trotzig \& Valhne 1989).

${ }^{7}$ In Sweden and England such a development is already under way - reflected in seminars and debates about research priorities and forms of cooperation (Thomas unpublished; Riksantikvarieämbetet 1995; Meta 93:2; Kyhlberg 1991\&1995).

${ }^{8}$ This is reflected in frequent reorganisations of the heritage sector in most countries. Denmark, Norway and Sweden have been through the process recently, leading to constructive (although also sometimes painful) debates about aims and means (e.g. Handlingsplan 1992; Norges forskningsråd 1994; Ams 91:6 from Norway). Also the tendency towards privatisation has led to much recent debate (Seminar report from BadenWürtenberg: Archäeologische Denkmalpflege und Grabungsfirmen).

\section{REFERENCES}

Adolfsson, G. 1987. Människa och objekt $i$ smyckeskrin. En analys av arkeologiska utställningar i Sverige. Symposion Bokförlag \& Tryckeri AB.

AmS-Rapport 6, 1991. Fornminnevernet i 1990årene. Norsk arkeologmöte i Stavanger 1990.

Andersson, E., Dahlgren, M. \& Jennbert, K. (eds.) 1995. Arkeologi och Förmedling. University of Lund, Inst. of Arch. Report Series No. 54.

Andersson, H. 1995. Arkeologisk forskning och uppdragsarkeologi. In Riksantikvarieämbetet 1995: Strategier för arkeologisk kunskapsuppbyggnad.
Baker, F. \& Thomas, J.(eds.) 1990. Writing the Past in the Present. Saint Davids University. Lampeter.

Baudou, E. 1991. Hur den arkeologiska forskningen styrs i Sverige. In: Larsson, L. \& Ryberg, E. (eds.): Arkeologi och Makt. Univ. of Lund, Inst. of Arch. Report Series No. 40.

Bender, B. (ed.) 1993. Landscape: politics and perspectives. Oxford.

Berglund, B.E. (ed.) 1991. The cultural landscape during 6000 years in southern Sweden - the Ystad Project. Ecological Bulletins No. 41.

Binford, L. 1983. In Pursuit of the Past. Decoding 
the archaeological record. Thames and Hudson.

Boniface, P. \& Fowler, P. 1993. Heritage and Tourism in "the Global Village". Routledge.

Bradley, R. 1993. Altering the Earth. The origins of monuments in Britain and continental Europe. Edinburgh: Society of Antiquaries of Scotland.

Deetz, J. 1977. In Small Things Forgotten: the archaeology of early American life. Doubleday, New York.

Fischer, A. \& Kristiansen, K. (eds.) in press. The Birth of Ecological Archaeology. Sheffield Univ. Press.

Fowler, P.J. (ed.) 1972. Archaeology and Landscape. John Baker London.

Friedman, J. 1989. Culture, identity and world process. In: Miller, D.; Rowlands, M. \& Tilley, C. (eds.): Domination and Resistance. One World Archaeology 3. London: Unwin Hyman.

Gathercole, P. \& Lowenthal, D: (eds.) 1990. The Politics of the Past. One World Archaeology 12. London Unwin Hyman.

Gillberg, A. \& Karlsson, H. 1994. Arkeologisk identitet inför 2000-talet - konservativ eller kritisk verksamhet? Kontaktstencil XXXVII. Teori \& praktik. Red. J. Goldhahn.

Gledhill, J., Bender, B. \& Larsen, M.T. (eds.) 1988. State and Society. The Emergence and Development of Social Hierarchy and Political Centralization. One World Archaeology 4. Unwin Hyman.

Grayson, D.K. 1983. The Establishment of Human Antiquity. Academic Press.

Habermas, J. 1973. Erkenntnis und Interesse. Mit einem neuen Nachwort. Suhrkamp.

Handlingsplan for kulturminnesforvaltning 1992. Innstilling fra et utvalg oppnevnt av miljøverndepartementet 7. september 1990. Oslo.

Hedeager, L.\& Schousboe, K. (eds.) 1989. Brugte historier. Ti essays om brug og misbrug af historien. Det Humanistiske Forskningscenter, Köbenhavns Universitet. Akademisk Forlag.

Hjørungdal, T. 1995. Gender-Critical Archaeology in Sweden. A Review. Current Swedish Archaeology, Vol. 3. The Swedish Archaeological Society.

Hodder, I. (ed.) 1991. Archaeological Theory in Europe. The Last Three Decades. Routledge.

- 1982a. The Present Past. An introduction to anthropology for archaeologists. Batsford Ltd.
- 1982b. Symbols in Action. Ethnoarchaeological studies of material culture. New Studies in Archaeology. Cambridge University Press.

- 1986. Reading the past. Current approaches to interpretation in archaeology. Cambridge University Press.

- 1989. Writing archaeology: site reports in context. Antiquity, Vol. 63, No. 239.

Hodges, R. 1991. Wall-to Wall History. The Story of Roystone Grange. Duckworth.

Horne, D. 1984. The Great Museum. The Re-presentation of History. Pluto Press.

Hyenstrand, Å. 1983. Kulturlandskap och bebyggelsehistoria. Kring ett forskningsfält med exempel frăn forntid och medeltid. Arkeologiska rapporter från inst. för arkeologi vid Stockholms universitet. Nr. 13.

- 1984. Fasta fornlämningar och arkeologiska regioner. Riksantikvarieämbetet och Statens Historiska Museer, Rapport RÄ̈ 1984:7.

- 1995. Arkeologi som samhälleligt fenomen. In: Riksantikvarieämbetet 1995: Strategier för arkeologisk kunskapsuppbyggnad.

Jensen, J. 1992. Thomsens Museum. Historien om Nationalmuseet. Gyldendal.

Keller, C. 1978. Arkeologi - virkelighetsflugt eller samfunnsformning. Universitetsforlaget, Oslo.

- 1991. Et eksempel på hvordan politiske strömninger har påvirket historisk og arkeologisk teoridannelse. In: Larsson, L. \& Ryberg, E. (eds.) Arkeologi och Makt. Univ. of Lund, Inst. of Arch. Report Series No. 40.

Kohl, P. 1993. Nationalism, politics and the practice of archaeology in Soviet Transcaucasia. Journal of European Archaeology. Vol. 1.2.

Kontaktstencil XXXV 1991. Arkeologi \& etnisitet. Kontaktseminaret i Oslo 6-12 okt. 1991.

Kristiansen, K. (ed.) 1985. Archaeological Formation Processes. The representativity of archaeological remains from Danish prehistory. Nationalmuseet.

Kristiansen, K. 1981. A social history of Danish Archaeology (1805-1975). In: Daniel, G. (ed.): Towards a History of Archaeology. Thames and Hudson.

- 1993. 'The strength of the past and its great might'; an essay on the use of the past. Journal of European Archaeology, Vol. 1.1.

- in press. Kulturmiljö 2000. Upubliceret strategirapport fra Skov- og Naturstyrelsen, Miljöministeriet.

Kyhlberg, O. 1991. Arkeologisk uppdragsverk- 
samhet. Perspektiv på 90-talet. I Kulturmiljövård 2, 1991

- 1995. Arkeologisk kunskapsdualism, kulturmiljövård-universitetsforskning. In: Riksantikvarieämbetet 1995: Strategier för arkeologisk kunskapsuppbyggnad.

Layton, R. (ed.) 1989. Conflict in the Archaeology of Living Traditions. One World Archaeology 8. Unwin Hyman.

Leone, M. 1984. Interpreting ideology in historical archaeology: using the rules of perspective in the William Paca garden in Annapolis, Maryland. In: Daniel Miller \& Christopher Tilley (eds.): Ideology, Power and Prehistory. Cambridge University Press.

Lowenthal, D. 1985. The Past is a Foreign Country, Cambridge University Press.

Macinnes, L. \& Wickham-Jones, C. (eds.) 1992. All Natural Things. Archaeology and the Green Debate. Oxbow Monographs 21.

Mahler, D. L., Paludan-Müller, C. \& Hansen, S. Stumann 1983. Om arkäologi. Forskning, formidling, forvaltning - for hvem? Hans Reizels Forlag.

Meltzer, D. J., Fowler, D. \& Sabloff, J. (eds.) 1986. American Archaeology. Past and Future. A Celebration of the Society for American Archaeology 1935-1985). Society for Am. Arch. and Smithsonian Institute Press. Washington.

Merriman, N. 1991. Beyond the Glass Case. Leicester University Press.

Miller, D., Rowlands, M. \& Tilley, C. (eds.) 1989. Domination and Resistance. One World Archaeology 3. London: Unwin Hyman.

Myhre Nordenborg, L. 1994. Arkeologi og poli$t i k$. Varia Nr. 26. Universitetets Oldsakssamling.

Nordbladh, J. 1991. Ingen tobak - inget halleluja. Forskarutbildningens dilemma: mötesplats för frihetskamp och maktsträvanden. In: Larsson, L. \& Ryberg, E. (eds.) Arkeologi och Makt. Univ. of Lund, Inst. of Arch. Report Series No. 40.

Norges Forskningsråd 1994. Vurdering af behovene for kulturminnvernforskning. Utredning utarbeidet av en gruppe nedsat av Nasjonal komite for miljøvernforskning. Oslo.

Näss, J.-R. 1991. Om maskering av makt og ukjente (?) kulturbariärer i nordisk arkeologi. In: Larsson, L. \& Ryberg, E. (eds.) Arkeologi och makt. Univ. of Lund, Inst. of Arch. Report Series No. 40.

Pinsky, V. \& Wylie, M.A. (eds.): 1989. Critical
Traditions in Contemporary Archaeology. Cambridge University Press.

Prentice, R. 1993. Tourism and Heritage Attractions. Routledge.

Rathje, W. 1979. Modern material culture studies. In: Advances in Archaeological Method and Theory, Vol. 2. Academic Press.

Rathje, W. \& Schiffer, M. 1980. Archaeology. Harcourt Brace Jovanovich, Inc.

Renfrew, C. 1983. Divided we stand: aspects of archaeology and information. American Antiquity, Vol. 48, No.1.

Riksantikvarieämbetet 1995. Strategier för arkeologisk kunskapsuppbyggnad. RA Ä's arkeologikonferens i Jönköping 11-12 november 1993.

Riksantikvarieämbetet 1993. Kulturarvet $i$ antikvarisk teori och praktik. Möte på Aronsborg $\mathrm{d}$. 4-5 april 1990.

Roymans, N. 1995. The cultural biography of urnfields and the long-term history of a mythical landscape. Archaeological Dialogues, Vol.2.1. Dutch Perspectives on Current Issues in Archaeology.

Schiffer, M. 1987. Formation Processes of the Archaeological Record. University of New Mexico Press.

Shanks, M. 1992. Experiencing the Past: on the character of archaeology. London: Routledge.

Shanks, M. \& Tilley, C. 1987. Re-Constructing Archaeology. Theory and Practice. New Studies in Archaeology. Cambridge University Press.

Shennan, S.(ed.) 1989. ArchaeologicalApproaches to Cultural Identity. One World Archaeology 10. London, Unwin Hyman.

Slapsak, B. 1993. Archaeology and the contemporary myths of the past. Journal of European Archaeology, Vol. 1.2.

Smith, L. 1994. Heritage management as postprocessual archaeology? Antiquity, Vol. 68, No. 259.

Sörensen, M.L. Stig 1984. Changing Images of Archaeology. South Scandinavian Archacology 1818 to 1978. Archaeological Review from Cambridge, Vol, 3:1.

Thomas, R. 1991. Drowning in data? - publication and rescue archaeology in the 1990s. Antiquity, Vol. 65, No. 249.

Thomas, R. unpublished. Where next? Paper given at the IFA 1994 Annual Conference, Bradford. Tilley, C. 1989. Excavation as theatre. In: Trotzig, 
G. \& Valne, G. (eds): Archaeology and Society. Large scale rescue operations - their possibilities and problems. ICOMOS/ICAHM Stockholm 88. ICAHM Report No. 1. Same in Antiquity, Vol. 63, No. 239.

Trigger, B. 1989. A History of Archaeological Thought. Cambridge University Press.

Trotzig, G. \& Valhne, G. (eds.) 1989. Archaeology and Society. Large scale rescue operations their possibilities and problems. ICOMOS/ ICAHM. Papers presented at the symposium in Stockholm 12-16 september 1988. ICAHM Report No.1.

Verband der Landesarchäologen in der Bundesrepublik Deutschland 1993. Archäologische Denkmalpflege und Forschung. Kolloquium Anlässich der Jahrestagung Weimar 18-21 Mai 1992. Thüringisches Landesamt für archäolo- gische Denkmalpflege.

Verband der Landesarchäologen in der Bundesrepublik Deutschland 1994. Archäologische Denkmalpflege und Grabungsfirmen. Kolloquium im Rahmen der Jahrestagung 1993 Bruchhsal, 10-13 Mai 1993.

Welinder, S. 1992. Människor och Landskap. Aun 15. Societas Archaeologica Upsaliensis.

- 1993. Miljö, Kultur och Kulturmiljö. Almquist \& Wiksell International.

- 1994. The Ethnoarchaeology of a Swedish Village. Current Swedish Archaeology, Vol. 2. The Swedish Archaeological Society.

- 1995. Swedish Society, Swedish Archaeology and the Public Debate. Current Swedish Archaeology, Vol. 3. The Swedish Archaeological Society. 